6. Майоров М. М. На путях к І съезду КП(б)У / М. М. Майоров // Летопись революции. -1928 . - № 4.

7. Правда. - 1919. - 26 февр.

8. Резолюції Всеукраїнських з'їздів Рад робітничих, селянських та червоноармійських депутатів. - Харків: Пролетарій, 1932. - 223 с.

9. Семенченко В. И. История Украины с древних времен до наших дней, изд. 2-е, исправленное и дополненное / В. И. Семенченко, Л. А. Радченко. - Харків: Торсинг, 1999. - 480 с.

10. Супруненко Н.И. Очерки истории гражданской войны и иностранной военной интервенции на Украине (1918-1920) / Н. И. Супруненко. - М.: Наука, 1966. - 455 с.

11. Українська революція 1917-1921 рр. на Придніпров'ї / Державний архів Дніпропетровської області; уклад. Ю. Г. Пахоменков, Н. Л. Юзбашева; ред. Н. Л. Юзбашева. - Дніпро: Ліра, 2016. - 372 с.

12. ЦДАВО України. - Ф. 1. - Оп. 1. - Спр. 7в, ч. 1. - Арк. 64 - копія.

13. ЦДАВО України. - Ф. 1. - Оп. 1. - Спр. 7в, ч. 1. - Арк. 57 - копія.

Надійшла до редкол.: 12. 03. 2018

\title{
Репресивна політика влади в металургійній промисловості Катеринославщини в 1920-х рр.
}

Кабанов В. І.

Дніпровський національний університет імені Олеся Гончара

Висвітлено репресії проти «старої» технічної інтелігенції в металургійній промисловості 1920-х рр., яка звинувачувалася в «шкідництві».

Ключові слова: репресії; «шкідництво»; металургійна промисловість; технічні спеціалісти; Україна; Німеччина; трест; завод; обладнання

Освещены репрессии против «старой» технической интеллигенции в металлургической промышленности 1920-х гг., обвиняемой во «вредительстве».

Ключевые слова: репрессии; «вредительство»; металлургическая промышленность; технические специалисты; Украина; Германия; трест; завод; оборудование.

In the presented article relying on archival sources and literature the author highlights problems in the metallurgical industry during the period of industrialization. The reconstruction of metallurgy according the decision of the communist government was carried out using the experience of the highly developed industry of Weimar Germany. According to the Soviet-German agreements, Ukrainian engineers visiting Germany ordered equipment to Ukraine from German companies.The management of trusts and factories for various reasons could not give a sake and it was spoiled. 
That was due to a number of reasons: the urgency of orders for imported equipment, the transition of enterprises to economic calculation, non-fulfillment of customer requirements by the trade representation, the delay of technical documentation, the lack of standardization of equipment. The administrative influence did not solve the problems, and the communist government and the repressive apparatus put the guilt on the «wreckers» - and the old technical intelligentsia, subjected itto destructive repressions. The Soviet state security agencies arrested the management board members of the trust «Pivdenstal», as well as the factories of Lenin and of Petrovsky, «C», «Comintern», of Dzerzhinsky, Zaporizhstal and others.

The massacres over the technical intelligentsia not only tragically affected the fate and life of thousands of highly skilled specialists, but also brought irreparable damage to the national economy. On the one hand, enterprises were deprived of competent, experienced technical managers, but on the other hand, left-wing engineers and technicians for the most part were demoralized. After the destruction of the old technical intelligentsia, its place was occupied by nominees from the workers, urgently prepared in Soviet educational institutions. Having no experience and solid knowledge in the conditions of mismanagement, imperfect economic mechanism, theft, they did not cope with the tasks and were also repressed, but as «saboteurs».

In future, it dishonored the USSR to lag behind the countries of the West in technical development.

Keywords: repressions; metallurgical industry; technical specialists; Ukraine; Germany; trust; plant; equipment

Проблема проведення репресивної політики радянської влади щодо технічної інтелігенції в 1920-х рр. в Україні вже знайшла своє відображення в студіях В. М. Даниленка, Г. В. Касьянова, С. В. Кульчицького, Ю. І. Шаповала, І. Г. Білас, С. Гнітько та ін. Серед дослідників цього питання на Дніпропетровщині треба згадати В. В. Іваненка, В. В. Ченцова, Д. В. Архірейського, Р. К. Терещенка тощо. Втім, цю проблему все ж не можна вважати цілковито розкритою. Тож завдання нашої розвідки полягає у тому, щоб висвітлити політичні репресії, які здійснювалися проти технічної інтелігенції в металургійній промисловості України, зокрема, з’ясувати їх мету та своєрідність під час реконструкції народного господарства республіки, яка проводилась на німецькому обладнані та за допомогою німецьких фахівців.

Треба зазначити, що в економіці України традиційно важливе місце посідали металургія та енергетика, від найшвидшого відновлення яких у післявоєнний період багато в чому залежала доля всієї економіки УСРР. Вдаючись до реалізації цієї масштабної програми, Україна звернулася до досвіду інших країн, передусім Німеччини. I це не випадково. Адже саме Німеччина після Першої світової війни досягла в цій сфері величезних успіхів, у короткий термін рекон- 
струювавши свої підприємства переважно шляхом раціонального постачання та використання сировини і палива, поліпшення виробничих процесів, вдосконалення обладнання.

Що ж стосується реконструкції металургії, то іiі розвиток в Україні передбачалося здійснювати, широко використовуючи досвід реконструкції металопромисловості Німеччини. У «Контрольних цифрах п'ятирічного плану розвитку промисловості УРСР 1928/29-1932/33 рр.» вказувалося: «... ми маємо можливість і повинні використовувати досвід Німеччини, яка тільки що докорінно реконструювала свої металургійні підприємства. Шлях Німеччини для нас ближче і легше дасть бажані результати» [16, с. 66].

Правильність орієнтації на запозичення зарубіжного, в тому числі німецького досвіду, підтвердила практика та саме життя. Особливе значення в цьому плані мало оснащення заводів новим обладнанням i, в першу чергу, силовими установками, засобами газо- i повітренадування та механізації. 3 цією метою Укрдержторг закупив за кордоном велику кількість різноманітного обладнання. Для «Південсталі», наприклад, було замовлено машин на 13.5 млн. руб, для «Південмаштресту» - на 1.5 млн. руб., для «Укртрестсільгоспмаша» на 1 млн. руб., для катеринославського та київського металооб'єднань - на 200 тис. руб. Крім того, Держторг ввіз велику партію спеціальних сортів сталі для виготовлення інструментарію та 300 тонн дроту для виготовлення металевих канатів [17]. Одночасно були закуплені кольорові метали (олово, цинк, алюміній, свинець) для заводів ім. Комінтерну, Таганрозького, ім. Леніна і Маріупольського на 2.1 млн. руб., а також чорні метали, інструментарій та контрольно-вимірювальні прилади [21, арк. 25]. Значна частина закупленого за кордоном обладнання припадала на Німеччину. Німецькі фірми не тільки постачали, але й направляли своїх фахівців-інженерів, майстрів, монтерів для його установки, монтажу та наладки.

Слід, однак, мати на увазі, що імпортне обладнання не завжди відповідало усім вимогами. Тому циркуляром ВРНГ СРСР від 7 липня 1927 р. 3 метою усунення недоліків пропонувалося оперативно направити відповідну інформацію в ІНО ВРНГ [14, арк. 4], а циркуляр по ВРНГ УРСР визначав порядок складання таких актів та рекламацій [14, арк. 6]. Для запобігання імпорту товарів, вироблених у СРСР, їх ввезення в країну наказом наркома торгівлі А. І. Мікояна було заборонено [23]. Використовуючи досвід закупівель обладнання в перші роки співпраці з іноземними фірмами, правління «Південсталі» 30 квітня 1930 р. ухвалило інструкцію 184 
«Про порядок проведення імпортних операцій», яка, з огляду на інтереси підприємств, встановлювала правила отримання замовлень, заявок, ліцензій, розміщення замовлень за кордоном, спостереження за експедиторсько-транспортними роботами, оплати і визначала коло організацій, зобов' язаних виконувати ці функції [15, арк. 284-287].

Незважаючи на вжиті заходи, на заводах «Південсталі» було виявлено чимало недоліків у питаннях приймання, використання і зберігання імпортного обладнання. Так, на підприємствах дніпропетровськоїгрупи «Південсталі» з 1925-26 рр. було замовлено імпортного обладнання на суму понад 9 млн. руб., надійшло до 1 квітня 1928 року на 3,7 млн. руб, а встановлено лише на 908 тис. руб [3, арк. 17]. Останне пояснювалося низкою причин: видачею замовлень до переведення підприємств на госпрозрахунок, їх терміновістю, недотриманням вимог замовника при укладанні договорів торгпредством, запізненням технічної документації (кошторису, креслення, копії замовлень, специфікації та ін.), неприйняттям заходів по стандартизації однорідного обладнання при видачі замовлень і т. ін. [3, арк. 17-18; 5, арк. 1, 11-12; 10, арк. 164; 11, арк. 57, 61, 64-66, 68; 13, арк. 92]. До того ж самі підприємства часто виявлялися не готовими до прийому нового обладнання, припускалися помилок у заявках, мала місце недбалість в його зберіганні і своєчасній установці. Тільки в 1928 р. на складах підприємств Дніпропетровського округу зберігалося імпортного обладнання на суму 5-6 млн. руб. [5, арк. 12]. 3 огляду на такий стан справ, бюро окружкома КП (б) У в своїй постанові «Про виконання рішень політбюро ЦК ВКП(б) від 8 серпня 1929 р. «Про роботу «Південсталі» запропонувало заводоуправлінням встановити такий порядок роботи, за яким на момент прибуття імпортного обладнання були б вже готові всі потрібні для нього споруди, фундаменти тощо, допускаючи лише як виняток зберігання його на складах [8, арк. 27].

Крім заходів адміністративного впливу, покликаних стабілізувати ситу-ацію в металургії, командна-адміністративна система почала практикувати і заходи репресивного характеру. В огляді ДПУ «Про політичний стан Дніпропетровського округу» від 25 червня 1928 р. зазначалося: «За принципом побудови шкідницької організації по Донуглю, нашими органами розкрита така ж шкідницька організація по Південсталі. У справі проходить верхівка організації - працівники правління Південсталі, по периферії з заводів Дніпропетровщини ім. Леніна, ім. Петровського, «С», «Комінтерна» [4, арк. 71]. 
Таким чином, провина вищих партійних і господарських керівників за прорахунки в плануванні розвитку галузі була перекладена на кадрових тех-нічних фахівців, яких звинувачували в «організації шкідництва» [4, арк. 71, 72; 20, с. 15]. На підставі цих звинувачень були проведені арешти. Особливий резонанс на підприємствах міста викликав арешт інженера К. Шпельті, відомого фахівця, який ще до революції разом із майстрами Дронсартом і Кошельським вивчав передовий досвід металургів Німеччини, завдяки чому був побудований єдиний в СРСР цех «Маннесман», який виготовляв суцільно катані труби [2]. Думку кадрового корпусу інженерів 3 цього приводу висловив начальник мартенівського цеху Лощилов: «Спецеєдство починає все більше позначатися. Якщо заарештували Шпельті, який відомий не тільки в СРСР, а й за кордоном, то з нами церемонитися не будуть i, безумовно, нас скоро спіткає та ж доля. За таких умов руки опускаються і працювати не має бажання» [9, арк. 59].

Заарештований органами ДПУ інженер П. Гогоцький, після відповідної «обробки» з боку чекістів, обмовив фахівців заводів ім. Петровського та ім. Леніна, інкримінувавши їм «суцільно брехливі» звинувачення. Проте, останні все ж «спрацювали» i, відповідно, з'явилися нашвидкоруч сфабриковані справи. Не зміг довести свою невинність і К. Шпельті. Також були заарештовані інженери А. А. Свіцин, С. М. Гуков, Козаков, Ф. Федоренко, Кузнєцов та ін., які, перебуваючи в Німеччині, зустрічалися з колишніми господарями підприємств або їх довіреними особами [6, арк. 107; 7, арк. 15]. Саме останні, за «визнанням» С. М. Гукова, давали директиви займатися шкідництвом, сприяти поверненню підприємств колишнім власникам на концесійних засадах [7, арк. 4]. Органи ДПУ викрили «шкідницьку організацію» на металургійному заводі ім. Дзержинського, яка упродовж 1929-1930-х рр. проводила там реконструкцію та пов'язане 3 нею капітальне будівництво. Тому і справа була запроваджена під назвою «Реконструктор». У складі організації діяло 11 осіб: головний інженер комбінату Д. С. Золотницький, головний інженер заводу П. Я. Кравцов, а також В. І. Котов, А. І. Колєсніков, О. М. Голованенко, Ф. Ф. Тхорш. У 1931 р. всі вони були засуджені «за систематичну групову «шкідницьку» діяльність 3 елементами диверсійного характеру» до різних строків перебування в таборах [18, с. 34, 161-162].

У грудні 1930 р. ДПУ УРСР розкрила «шкідницьку» організацію інже-нерів і техніків на рудниках Криворізького басейну, яка в ході слідства була визнана галузевим осередком «Промпартії». Очолював «шкідників» Е. К. Фукс, німець, колишній помічник управ- 
ляючого Новоросійського акціонерного товариства в Кривому Розі, досвідчений геолог. Фукс не визнавав таких нових методів роботи, як «соцзмагання, самокритика, ударництво, чистка, постійні ревізії, вимоги підвищених темпів роботи». Зрештою, судова трійка при колегії ДПУ УРСР 10 квітня 1931 р. засудила шість осіб до тривалих років ув'язнення в концтаборі, а Е. К. Фукс отримав 10 років. Незабаром він був звільнений і повернувся на роботу. Втім, після публікації у серпні 1937 р. в газеті «Червоний гірник» Е. К. Фукс у січні 1938 р. був знов заарештований за проведення «розвідувальної підривної роботи» $\mathrm{i}$ 2 квітня помер у віці 66 років, перебуваючи у в'язниці [22, с. 35-36].

В 1937 р. був заарештований директор комбінату «Запоріжсталь» I. 3. Рогачевський, звинувачений як член контрреволюційної організації в шпигунсько-диверсійній діяльності. В арешті I. 3. Рогачевського велику роль відіграло його відрядження в 1930 p. в Німеччину для закупівлі обладнання і вивчення передового досвіду металургійного виробництва. До того ж він працював у Торгпредстві в Берліні під керівництвом Ю. Пятакова (ворога Й. Сталіна), який і познайомив його із інженером фірми «Бром-Бовері» Шершнайдером - німецьким шпигуном. А вже останній, у свою чергу, начебто завербував його для шпигунської діяльності й шкідництва. У підсумку Військова колегія Верховного суду СРСР засудила I. 3. Рогачевського до розстрілу. Вирок було виконано 15 жовтня 1937 р. у Києві [19, с. 187-191].

Багаторічне переслідування фахівців із дореволюційним стажем призвело до майже повного знищення цього прошарку інтелігенції. Їх місця в промисловості зайняли «висуванці» з робітників, спішно підготовлені на курсах, в технікумах і вузах. Однак терор не слабшав. Змінилася тільки термінологія: визначення «шкідник» залишилося переважно за буржуазними фахівцями, а нові жертви стали називатися «саботажниками».

Репресії проти фахівців мали важкі наслідки для всіх галузей промисловості України. Уже після «Шахтинської справи» іiі синдром захопив і підприємства металургії, техперсонал яких став уникати відповідальності й конфліктних ситуацій із робітниками [20, c. 15]. Так, характеризуючи роботу та настрій фахівців заводу ім. Дзержинського, заступник управляючого Брачко в своєму звіті від 15 жовтня 1928 р. голові правління «Південсталі» С. Бірману писав, що «відкритого саботажу немає, але після «Шахтинської справи» вищий технічний персонал послабив керівництво над майстрами, а майстри, побоюючись критичного ставлення цехових організацій та 
робітників, зовсім випустили керівництво над останніми, внаслідок чого мало місце різке падіння продуктивності праці та послаблення уваги до виробничих процесів» [12, арк. 15]. Безперечно, зазначене не могло не відбитися на загальному ритмі роботи заводу, призвело до численних поламок та аварій [12, арк. 15-17].

Зрештою, загальні масштаби втрат інженерного корпусу, початок яких поклала «Шахтинська справа», ще не визначені. Але цілком зрозуміло, що вони були величезні. Не випадково, що у виступі начальника об’єднання «Сталь» М. Г. Мишкова на червневому (1931р.) пленумі ЦК КП(б)У підкреслювалося, що на результат роботи дуже впливає нестача інженерів і техніків, багатьох із яких заарештовано органами ДПУ [1, с. 85].

Незважаючи на великі втрати, яких металургія України зазнала від репресій, на підприємствах ім. Дзержинського, ім. Томського, ім. Ворошилова та ін., не без допомоги німецьких фірм була проведена докорінна, а на багатьох - часткова реконструкція, що дозволило помітно розширити виробничі потужності, збільшити виплавку чавуну та сталі, дати мільйони рублів економії народному господарству України. Застосувавши німецький досвід реконструкції металургії, Україна в подальшому будувала також нові цехи і заводи за американськими зразками, які вирізнялися значними обсягами виробництва. На початку 1930-х рр. у металургії, машинобудуванні та інших галузях промисловості був узятий курс на скорочення іноземних поставок і звільнення країни від імпортної залежності.

Сучасні вчені стверджують, що шкідництва як свідомої політики, яка проводиться цілим шаром «буржуазних фахівців», не існувало. Насправді мав місце розквіт безгосподарності, недосконалість господарського механізму, відсутність кваліфікованих робітничих кадрів, низька продуктивність праці, нестача сучасної техніки, брак знань та некомпетентне управління з боку «червоних директорів», а також простої, аварії, злодійство, хабарництво, які необхідно було виправдати в очах народу пошуком прихованих ворогів. Отже, метою судових процесів проти «шкідників» було прагнення відвернути невдоволення широких мас від компартійного керівництва, яке за будь-яку ціну прагнуло в найкоротші терміни здійснити масштабну індустріалізацію промисловості. 


\section{БІБЛІОГРАФІЧНІ ПОСИЛАННЯ}

1. Даниленко В. М. Сталінізм на Україні: 20-30-ті роки / В. М. Даниленко,

Г. В. Касьянов, С. В. Кульчицький. - Київ: Либідь, 1991. - 344 с.

2. Звезда. - 1923. - 18 дек.

3. Державний архів Дніпропетровської області (далі - ДАДО). - Ф. п. 7, оп. 1, спр. 743.

4. ДАДО. - Ф. п. 7, оп. 1, спр. 874.

5. ДАДО. - Ф. п. 7, оп. 1, спр. 1036.

6. ДАДО. - Ф. п. 7, оп. 1, спр. 1501.

7. ДАДО. - Ф. п. 7, оп. 1, спр. 1600.

8. ДАДО. - Ф. п. 305, оп. 1, спр. 90.

9. ДАДО. - Ф. 1393, оп. 1, спр. 1.

10. ДАДО. - Ф. 2146 оп. 1, спр. 40.

11. ДАДО. - Ф. 2146 оп. 1, спр. 60.

12. ДАДО. - Ф. 2160 , оп. 1, спр. 5.

13. ДАДО. - Ф. 2160 оп. 1, спр. 11.

14. ДАДО. - Ф. 2161, оп. 1, спр. 2.

15. Державний архів Донецької області. - Ф. p - 231, оп. 1, спр. 553.

16. Контрольные цифры пятилетнего плана развития промышленности УССР. 1928-1929 - 1932-1933 гг. - Харьков, 1929. - 369 с.

17. Коммунист. - 1926 г. - 14 марта.

18. Реабілітовані історією: У 27 т. Дніпропетровська область: У 2 кн. / Упорядники: С. І. Бородін, О. Г. Бажан, В. В. Іваненко, Л. Л. Прокопенко, Р. К. Терещенко. - Кн. 1. - Дніпропетровськ: Вид-во «Монолит», 2009. - 880 с. 19. Реабілітовані історією (Запорізька область): Науково-документальне видання. - Запоріжжя: Дніпровський металург, 2004. - 584 с.

20. Спадщина. - 1992. - № 3. - С. 15.

21. Центральний державний архів вищих органів влади та управління України. - Ф. 106, оп.1, спр. 812.

22. Ченцов В. В. Трагические судьбы. Политические репрессии против немецького населения Украины в 1920-1930-е годы / В. В. Ченцов. - М.: Готика, 1998. - 208 с. 23. Экономическая жизнь. - 1927. - 1 февр.

Надійшла до редкол.: 02. 04. 2018 